\title{
Thinking Critically About Business Ethics
}

F. Peter Dean (E-mail: fpdean@joink.com), Indiana State University

Mary Ann Boose (E-mail: isboose@isugw.indstate.edu), Indiana State University

\begin{abstract}
In this study, we teach students and business professionals to apply a formal process of critical thinking to the issues of business ethics. Every new scandal generates a renewed interest in business ethics, leading the news media and the public to lament the current state of affairs, sometimes asking why colleges and schools of business don't do a better job of teaching ethics. Many suggest that business owners and managers do not act as ethically as in the past. Some say that they cannot act ethically. The critical thinking skills and examples included in this study can serve to help students of business and professionals in business as they approach difficult ethical decisions.
\end{abstract}

\section{Introduction}

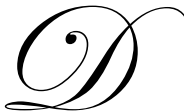

aily headlines are replete with the results of poor decisions on the part of business professionals. From board members to accountants, from hazardous materials to powerful pens, top business executives, and their junior colleagues, are making decisions that do not conform to sound moral practice and are harmful to other people and to the environment, both physical and corporate. Are these decision-makers intentionally hurting others for their own benefit? If some are, is that true throughout the firm? The authors assert that most humans aspire to do the "right thing" under most circumstances. It is not moral fiber that is lacking, but the skills (and practice) at good ethical decision-making. This paper offers a set of questions to guide decisionmakers who are faced with difficult choices, then presents a decision-making template based on sound ethical theory and demonstrates how it may be used. For those interested in a quick review of ethics theory, an appendix reviews current thought.

Most people, including most business managers, have no formal training in business ethics (Dean 2001). It is not that they do not want to act ethically. Evidence of the intent of the majority of professionals is presented by the number of professional codes of ethics, prayer breakfasts, retreats, and other activities directed at, led by, and participated in by business managers and professionals. Unfortunately, these activities are seldom grounded in theory, even if they do address the specifics of modern business; so the desire of business managers to "do the right thing" needs further direction. Further, professional codes and religious scripture require so much interpretation for application that they may be impracticable as guides to the real business world. Critical thinking skills are required in order to turn established guides into meaningful roadmaps for success in ethical decision-making.

Adding significantly to the decision-making difficulty for most business professionals is the fact that business ethics is rational philosophical ethics practiced in the business environment. The mistake that many people make is to think that business ethics is some special kind of ethics. It is, in fact, grounded in the basics of ethical theory, as well as in the critical thinking skills necessary to operationalize ethics theory. As such, study of the basic theory and the use of critical thinking skills to apply the theory to modern business are both required. The same theories are practiced in all ethics; the same critical thinking process must be used; and the same criteria of right and wrong are applied. Appending "business" to "ethics" only designates the environment in which one practices ethics and suggests the scope of issues likely to be addressed.

Our main tool in analyzing business and the ethics that should be practiced in the business environment will be critical thinking as described by Paul and Elder (2001). Specifically, we will refer to the elements of thought that they have designated. Before we attack the problem of ethics in business we think critically about business itself. 


\section{Definitions}

Business, as it is used here, refers to any organization that trades goods for money with the anticipation of gain. As the ideas associated with business and business practices themselves vary widely around the world, we will focus on business in the U.S. Three important basic concepts must be kept in mind throughout our discussion. First, operating a business is not a right. It is a limited privilege granted by organized society. It generally requires licenses, registration, public reports, etc. Society is entitled to, and does, demand that business serve some useful and lawful purpose. Second, a business is an artificial person. This is true in a legal sense for corporations, but we extend it here to include any business. As a result, when we refer to a business making a decision or acting, we understand that natural persons (owners or managers) are choosing and acting in the name of the business. Finally, business failure is not a moral failure. The purely economic result of any business is of no ethical concern. The processes that are employed in achieving those economic results may be of great ethical concern.

Ethical decision-making is defined as any decision-making that is accomplished in any context in which there is a moral issue at stake. That is, in any context in which benefits or harms may result from the proposed action. It is possible that the actor realizes the implications, and acts in a harmful manner intentionally and understanding the nature of his or her decision. This is also ethical decision-making. In the discussion that follows, the authors take the position that all business professionals should to do the ethically right thing in order to justify the privilege granted by society. No richness of context is sacrificed.

Critical thinking, simply defined, is second order thinking. That is, critical thinking is real time thinking about our thinking. It responds to questions like: Why is this important? How can we make a good decision?

\section{Critical Thinking}

The critical thinking process used here is fully described by Paul and Elder (2001a, and 2001b) Each of these books is appropriate for the use of business students. As a brief outline, and to provide a sense of the critical thinking process used here, we note that Paul and Elder describe the elements of thought as an understanding of the following items as related to the issue at hand. 1) The purpose of our thought; 2) The question, issue, or problem that we are addressing; 3) The assumptions that we are using; 4) Our own point of view from which we see the issues; 5) All of the relevant information available including all vital information that must be gathered in order to reach a rational decision; 6) The concepts or ideas that are applicable to the issue at hand; 7) The inferences and interpretations generated from examination of the assumptions, point of view, information, and concepts that have been assembled; and, finally, 8) The conclusions, implications and consequences that arise from our consideration of all these. When we teach critical thinking, we find that separating "conclusions" from "implications and consequences" clarifies matters for students. The result of this separation is shown throughout this paper.

Paul and Elder also require that critical thinking be evaluated by applying Universal Intellectual Standards which they define as: Clarity, Accuracy, Precision, Relevance, Depth, Breadth, Logic, Significance, and Fairness. If this is not a definitive list, it does form a sound basis for evaluating thought. Paul and Elder explain these standards fully.

Paul and Elder continue by contrasting Intellectual Virtues and Vices. We have taken a somewhat more Aristotelian approach as indicated in Table 1 below by identifying vices of insufficiency as well as vices of excess. Practice of the intellectual virtues strengthens the student's skill at using the formal process of critical thinking. Identification of any of the vices in an author's or student's work suggests that one should be suspicious of conclusions reached in that work. There is no doubt that these are intellectual virtues we wish our students to adopt. 
Table 1. Intellectual Virtues and Vices

\begin{tabular}{|l|l|l|}
\hline Vice of Insufficiency & Virtue & Vice of Excess \\
\hline Abandonment of Self Respect & Intellectual Humility & Intellectual Arrogance \\
\hline Intellectual Cowardice & Intellectual Courage & Intellectual Foolhardiness \\
\hline Close-mindedness & Intellectual Empathy & Emotionalism \\
\hline Intellectual Conformity & Intellectual Autonomy & Intellectual Perversity \\
\hline Intellectual Hypocrisy & Intellectual Integrity & Intellectual Self-Righteousness \\
\hline Intellectual Sloth & Intellectual Perseverance & Intellectual Stubbornness \\
\hline Distrust of Reason \& Evidence & Confidence in Reason & Dismissal of Other Inputs \\
\hline Unfair Prejudice & Fair-mindedness & Unfair Favoritism \\
\hline
\end{tabular}

While this provides a quick overview of Paul and Elder's treatment of critical thinking it can not substitute for a thorough grounding in the study of critical thinking. Critical thinking is so fundamental to higher education that it surprises us that very few students encounter an opportunity to learn explicitly what constitutes this skill.

\section{Elements Of Thought Applied To Business (Uncritically)}

If people, including business owners and managers, thought consciously about business, their thoughts could probably be tabulated to look something like Table 2 .

Table 2. Common Thinking About Business

\begin{tabular}{|c|c|}
\hline Purpose & Profit \\
\hline Question, Issue, Problem & How can I maximize profit from my investment? \\
\hline Assumptions & Owners should make the maximum profit from business \\
\hline Point of View & $\begin{array}{l}\text { 1. Business Owner. } \\
\text { 2. Business Manager. }\end{array}$ \\
\hline Information & $\begin{array}{l}\text { 1. No one else is interested, or will help, owners to make profits. } \\
\text { 2. It is necessary to provide goods to others in exchange for their money. } \\
\text { 3. We must pay others as little as possible in order to make a profit. }\end{array}$ \\
\hline Concepts & 1. Private Property \\
\hline Ideas & $\begin{array}{l}\text { 2. The way markets work: rational self interest, symmetry of information, no dominant play- } \\
\text { er, supply/demand relationships, etc. }\end{array}$ \\
\hline Inferences & 1. Buy low \& sell high \\
\hline Interpretations & $\begin{array}{l}\text { 2. Minimize costs of materials, labor, overhead, etc. } \\
\text { 3. Maximize prices. }\end{array}$ \\
\hline Conclusions & $\begin{array}{l}\text { Produce the cheapest goods that someone will buy and sell it for the highest price they will } \\
\text { pay. }\end{array}$ \\
\hline $\begin{array}{l}\text { Anticipated } \\
\text { Implications \& } \\
\text { Consequences }\end{array}$ & $\begin{array}{l}\text { 1. Poor Quality goods. } \\
\text { 2. Low wages. } \\
\text { 3. Minimum worker benefits. } \\
\text { 4. Jungle-like competition. }\end{array}$ \\
\hline
\end{tabular}

Table 2 is obviously very much simplified. There are many more issues and questions; much more information; more assumptions; and even other ways of stating the purpose, e.g., increasing the wealth of owners. But, this analysis serves the purpose of representing the popular notion of business and what it is about. Unfortunately, many business owners and managers believe that these ideas are basically correct. They then act on this basis. The problem for ethicists and for the rest of society is that, in this rationale, there is no place for a consideration of ethics. There are inherent flaws in this view. 


\section{Who Or What Is The Business?}

The first problem we encounter is that the above pattern of thinking conflates the interests of the business with the interests of business owners. As mentioned above, the business is an entity separate from its owners, and therefore has interests of its own, the first among them being survival. This suggests that a company may have different purposes than its owners. Table 2 provides a good description of the thinking of some business owners, especially some of those who invest in corporate stock. Business survival depends, instead, on an unwavering focus on the purposes that directly affect the viability of the organization.

\section{Elements Of Thought Applied To Business (Critically)}

The flaws in thinking begin with a misunderstanding of the purpose of the firm. Is profit (or enriching owners) the purpose of business? Profit is literally the bottom line for business. That is, when we account for all revenues and costs associated with the business and calculate the difference we find a result. When we think of "purpose" intention, idea, and design are essential factors in our minds. We think about what we will do, not only of the results of our action. Purpose, then, emanates from the mission of the firm, not from the "bottom line."

Let's try another approach to purpose. The Random House Unabridged Dictionary ( $2^{\text {nd }}$ ed.) gives as the first definition of purpose, "the reason for which something exists or is done, made, used, etc." This "reason" logically precedes the existence of the thing or the doing, making, or using. For everything is done or made for a reason (Aristotle, NE). First we have a reason to act. Only then do we act, or make, or bring something into existence. Again, we see the logic of things. If profit is the last thing we learn about our business, it surely cannot precede the existence or doing of business. If indeed, profit is a (much desired) result, what is it a result of? Here, I suggest the obvious: Profit is the result of doing business well, i.e., carrying out our purpose effectively and efficiently. Rationality (business claims to be rational) requires that we find another purpose for business.

Is it any wonder that so many businesses are in trouble when we recognize that their owners and managers confuse the purpose of their business with the results?

We have a few clues as to what the purpose of business may be. In the above analysis we recognized that we must provide goods in order to realize revenues. We also recognize that we have no help or cooperation in realizing our purpose, if that purpose is narrowly egoistic, i.e., profit. No customer buys shoes, no employee runs a machine, no supplier provides raw materials, in order for some company to make a profit. How can we improve our chances of success? We need all the help we can get. Specifically, we need loyal customers, honest suppliers, and the best, most effective, employees that we can find. Without those, the competition is likely to bury us.

This suggests that we may want to focus on the needs of others (customers, suppliers, and employees). We often find that the best way to obtain a desired result is to approach it by an indirect route. This is the case in many personal relationships. Neglecting direct action in favor of simply going about our lives and acting reasonably until the problem solves itself is frequently more effective than confrontation. In the case of business, we might best realize a profit by focusing on those matters that lead to a business that deserves a profit; that has earned it. Not surprisingly, this is just what society demands in exchange for granting the privilege of doing business.

In addressing the problems that we have already acknowledged: providing goods and recruiting help in our endeavor, we find a management theory that helps. W. Edwards Deming suggests in his book "Out of the Crisis" that business has two purposes: (1) Satisfy the needs of a market, and (2) Create good jobs. Note that these purposes are also consistent with business' obligations toward society. One may argue that even the creation of good jobs is a result of serving the needs of a market. Using the single purpose of satisfying the needs of a market, we'll try to build a more rational understanding of the business enterprise itself.

Like all of the Tables in this paper, Table 3 is simplified. These tables represent only an outline of topics considered; not a detailed record of anyone's critical thinking on the subject. Much more could be added in every category. Most obviously, almost every statement leads to questions of meaning, justification, and interpretation. Nevertheless, we can accept this as a minimal outline of the logic of business and turn to the issue of business ethics based on an understanding of this logic. 
Table 3. Thinking Critically About Business

\begin{tabular}{|c|c|}
\hline Purpose & 1. Satisfy the needs of a market. \\
\hline $\begin{array}{l}\text { Question } \\
\text { Issue } \\
\text { Problem }\end{array}$ & $\begin{array}{l}\text { 1. What market shall we try to satisfy? } \\
\text { 2. What are that market's needs? } \\
\text { 3. How can we best satisfy the needs of that market? }\end{array}$ \\
\hline Assumptions & $\begin{array}{l}\text { 1. Owners should profit from business if it is done well. } \\
\text { 2. Satisfying the needs of a market efficiently and effectively constitutes doing business well. } \\
\text { 3. Jobs that are rewarded adequately to provide a respectable living for employees and their dependants } \\
\text { constitute "good' jobs. } \\
\text { 4. Good jobs result from satisfying the needs of a market. }\end{array}$ \\
\hline $\begin{array}{l}\text { Points } \\
\text { of View }\end{array}$ & $\begin{array}{l}\text { 1. Business Owners. } \\
\text { 2. Business Managers }\end{array}$ \\
\hline Information & $\begin{array}{l}\text { 1. Others are interested, and will help, business in order to satisfy their own needs. } \\
\text { 2. Others will pay business to satisfy their needs. } \\
\text { 3. Employees will work effectively to earn a respectable living. } \\
\text { 4. We must pay others fairly in order to stay in business. This includes labor and suppliers. }\end{array}$ \\
\hline $\begin{array}{l}\text { Concepts } \\
\text { Ideas }\end{array}$ & $\begin{array}{l}\text { 1. Private Property } \\
\text { 2. The way markets are expected to work: rational self interest, symmetry of information, no dominant } \\
\text { player, supply/demand relationships, etc. } \\
\text { 3. Effectiveness. } \\
\text { 4. Efficiency. }\end{array}$ \\
\hline $\begin{array}{l}\text { Inferences } \\
\text { Interpretations }\end{array}$ & $\begin{array}{l}\text { 1. Buy \& sell fairly. } \\
\text { 2. Manage long term costs of materials, labor, overhead, etc. to extract the maximum benefit for all who } \\
\text { are affected. } \\
\text { 3. Set prices fairly. }\end{array}$ \\
\hline Conclusions & Produce goods that truly satisfy market needs and sell them at fair prices. \\
\hline $\begin{array}{l}\text { Anticipated } \\
\text { Implications \& } \\
\text { Consequences }\end{array}$ & $\begin{array}{l}\text { 1. Acceptable Quality goods. } \\
\text { 2. Compensation of all involved, including owners, based on the level of market satisfaction provided by } \\
\text { the business. } \\
\text { 3. Competition based on level of market satisfaction. }\end{array}$ \\
\hline
\end{tabular}

\section{Ethics In Business}

Why does the issue of ethics arise in business? Why should business owners and managers act ethically? Convincing answers to these questions must be practical. After all, this whole discussion is merely an academic exercise if we cannot convince practicing business professionals that it is relevant. Even those business owners and managers who properly recognize their purpose exercise control over business methods and results. One way they define practicality is that it contributes to that control. So the question becomes: Does ethical conduct contribute to a manager's control of business methods and results? Even if ethics does not guarantee profit, does it at least help to minimize loss? Fortunately, the answers to these questions are: "Yes."

We have focused here on matters of trust. We could as well have focused on matters of fairness, justice, practical wisdom, law, compliance, contractual obligation, or on all of these. But the issue of trust is connected to all of these and seems sufficient to illustrate the process.

\section{Application Of Critical Thinking To Problems In Business Ethics}

Now the question arises: How does one apply these ideas? After all, it serves no purpose to merely understand an issue if we cannot implement that understanding in the real world. Now this example of critical thinking will necessarily set a new standard in simplification. We cannot fill in all the blanks until we define the issue/problem. 
Table 4. Thinking Critically About Business Ethics

\begin{tabular}{|c|c|}
\hline Purpose & Do the right thing in the business environment. \\
\hline Question, Issue, Problem & Should business act ethically? \\
\hline Assumptions & $\begin{array}{l}\text { 1. Purpose of business. (see Table 2.) } \\
\text { 2. Ethical behavior promotes trust. } \\
\text { 3. Unethical behavior diminishes trust. } \\
\text { 4. Acting for the general good is, in the long run, rewarded. }\end{array}$ \\
\hline Point of View & $\begin{array}{l}\text { 1. Business Owner. } \\
\text { 2. Business Manager. }\end{array}$ \\
\hline Information & $\begin{array}{l}\text { 1. Fiduciary relationships. } \\
\text { 2. Business requires trust of customers, suppliers, employees, financial institutions, legal regulators, } \\
\text { etc. } \\
\text { 3. Mistrust on the part of customers reduces revenues. } \\
\text { 4. Mistrust on the part of suppliers results in increased costs. } \\
\text { 5. Mistrust on the part of employees results in: } \\
\text { a. Loss of trustworthy employees who don't "fit in." } \\
\text { b. Increased turnover with its associated costs. } \\
\text { c. Replacement of trustworthy employees by untrustworthy employees who do "fit in." } \\
\text { d. Losses associated with untrustworthy employees. } \\
\text { 6. Mistrust on the part of financial institutions results in higher cost of capital. } \\
\text { 7. Coping with government regulators and law enforcement is expensive. } \\
\text { 8. On research, it can be shown that ethical behavior does encourage trust in all those mentioned } \\
\text { above. }\end{array}$ \\
\hline Concepts, Ideas & Philosophical Theories of Ethics. (See discussion in text below.) \\
\hline $\begin{array}{l}\text { Inferences } \\
\text { Interpretations }\end{array}$ & $\begin{array}{l}\text { 1. In order to gain needed trust, business act ethically. } \\
\text { 2. Unethical conduct resulting in mistrust will drive away customers, suppliers, employees, finan- } \\
\text { cial institutions, etc. } \\
\text { 3. Unethical behavior resulting in mistrust will attract government regulators and law enforcement. }\end{array}$ \\
\hline Conclusions & Business should behave ethically. \\
\hline $\begin{array}{l}\text { Anticipated } \\
\text { Implications \& } \\
\text { Consequences }\end{array}$ & $\begin{array}{l}\text { 1. Required trust will be generated. } \\
\text { 2. Company reputation will be enhanced with resulting benefits in sales, recruiting, relationships } \\
\text { with suppliers and government. } \\
\text { 3. Costs will be contained. } \\
\text { 4. Revenues will increase. } \\
\text { 5. Profit will be the most likely result. }\end{array}$ \\
\hline
\end{tabular}

Table 5a. Generic Critical Thinking About Particular Business Ethics Problems

\begin{tabular}{|c|c|}
\hline Purpose & To do the right thing in each particular business issue/problem. \\
\hline $\begin{array}{l}\text { Question } \\
\text { Issue } \\
\text { Problem }\end{array}$ & What to do about a particular problem in business. \\
\hline Assumptions & $\begin{array}{l}\text { 1. The specific purpose of this business. } \\
\text { 2. Ethical action in this matter is, in the long run, rewarded. }\end{array}$ \\
\hline $\begin{array}{l}\text { Point } \\
\text { Of View }\end{array}$ & $\begin{array}{l}\text { 1. Business Owner responsible for making decisions and acting on the issue. } \\
\text { 2. Business Manager responsible for making decisions and acting on the issue. } \\
\text { 3. Oneself in a personal context. }\end{array}$ \\
\hline Information & Ethically relevant matters regarding the issue/problem at hand. \\
\hline $\begin{array}{l}\text { Concepts } \\
\text { Ideas }\end{array}$ & $\begin{array}{l}\text { 1. Virtue. } * \\
\text { 2. Contractarianism.* }\end{array}$ \\
\hline $\begin{array}{l}\text { Inferences } \\
\text { Interpretations }\end{array}$ & Dependant on the problem at hand. \\
\hline Conclusions & Dependant on the problem at hand and relevant information. \\
\hline $\begin{array}{l}\text { Anticipated Implica- } \\
\text { tions \& Consequences }\end{array}$ & Dependant on the problem at hand and conclusions. \\
\hline
\end{tabular}


This, then, creates a template for thinking through the ethical dimension of any business problem. The italicized items must, of course, be completed in detail for each problem as it arises. The Pragmatist will ask: Will it work? In answer, experienced managers report that it does (Morris, 1997; Bowie, 1998; Moore,1999; The Economist, 2000). The general experience is that acting ethically is rewarded in the business world. Are there exceptions? Yes, sometimes the reward comes too late to save the business. Ethics is necessary but not sufficient for business success. Owners and managers must also operate the business efficiently and effectively. But even these conditions are intimately connected with ethics. One must act efficiently not only to make a profit, but because the waste of inefficiency is unethical: waste deprives others of resources that can improve their lives. The most obvious example is in food processing. We must practice effectiveness ethically too. Although it might seem effective to treat workers unfairly, that only works in the short term. In the long term we save by treating employees with justice: it reduces costs related to turnover, it improves quality, it creates customers of employees, and it enhances company reputation in the community, and it leads to generally favorable treatment by society.

Table 5b. Thinking Critically About Adopting A Diversity In Hiring Policy At MYCORP

\begin{tabular}{|c|c|}
\hline Purpose & To do the right thing in each particular business issue/problem. \\
\hline $\begin{array}{l}\text { Question } \\
\text { Issue/Problem }\end{array}$ & $\begin{array}{l}\text { Should we hire a diverse workforce? OR Should we limit new employees to those who look and sound like us } \\
\text { and believe as we do. }\end{array}$ \\
\hline Assumptions & $\begin{array}{l}\text { 1. Our purpose is to manufacture auto parts for OEMs and aftermarket resellers. } \\
\text { 2. Ethical action in this matter, in the long run, will be rewarded. } \\
\text { 3. The labor market has the same supply/demand relationship as other market segments. } \\
\text { 4. We should strive to be the best auto parts manufacturer that we can be in order to optimize our results. }\end{array}$ \\
\hline $\begin{array}{l}\text { Point } \\
\text { Of View }\end{array}$ & $\begin{array}{l}\text { 1. Board of Directors. } \\
\text { 2. All managers in the company who may have to make decision or act on this matter: Human Resource Man- } \\
\text { ager; Functional Department Managers. }\end{array}$ \\
\hline Information & $\begin{array}{l}\text { 1. All groups identifiable by culture, race, ethnicity, religion, lifestyle, sex, etc. have a distribution of talents } \\
\text { and skills such that many are suitable for any employment we offer. Even many handicapped people can } \\
\text { easily be equipped to do most of our jobs. } \\
\text { 2. We have competitors. } \\
\text { 3. The best employees prefer to work for the fairest employers. } \\
\text { 4. Legal requirements for a diverse workforce apply to us. } \\
\text { 5. We have accepted government contracts that require a diverse workforce. } \\
\text { 6. We live in a society in which discrimination is widely practiced. }\end{array}$ \\
\hline $\begin{array}{l}\text { Concepts } \\
\text { Ideas }\end{array}$ & $\begin{array}{l}\text { 1. Virtue Ethics; the practice of justice, courage, temperance, and prudence. } \\
\text { 2. Contractarianism; both implied and explicit. }\end{array}$ \\
\hline $\begin{array}{l}\text { Inferences } \\
\text { Interpretations }\end{array}$ & $\begin{array}{l}\text { 1. We will maximize our labor pool by diverse hiring practices. [Wisdom] } \\
\text { 2. We will have a competitive advantage relative to employers who artificially limit the size of their labor } \\
\text { pools. [Wisdom] } \\
\text { 3. We will be able to identify and hire the best employees for each position. [Courage, Wisdom, Justice] } \\
\text { 4. We should adhere to our contracted duties; else we could lose valuable government contracts. [Contract, } \\
\text { Temperance, Wisdom, Justice] } \\
\text { 5. We should obey the law; else we could be heavily fined. [Contract, Temperance, Wisdom, Justice] } \\
\text { 6. In order to become the best company we can be we need the best employees we can hire. [Courage, Wis- } \\
\text { dom, Justice] } \\
\text { 7. Discrimination is unjust, cowardly, intemperate, and unwise. [Virtue] }\end{array}$ \\
\hline Conclusions & MYCORP should adopt a policy of hiring a diverse workforce. \\
\hline $\begin{array}{l}\text { Anticipated } \\
\text { Implications \& } \\
\text { Consequences }\end{array}$ & $\begin{array}{l}\text { 1. We will have competitive advantages over those who limit themselves to recruiting only a portion of the total } \\
\text { workforce because our selection includes well-qualified workers who they reject. [Courage, Wisdom, Jus- } \\
\text { tice] } \\
\text { 2. Our employees will react positively to our explicit demonstration of fairness. [Wisdom, Justice] } \\
\text { 3. Trust between employees and management will increase. [Justice] } \\
\text { 4. We will have a larger pool of recruits for all openings thus reducing recruiting costs. [Wisdom] } \\
\text { 5. We will not lose a contract due to noncompliance with the diversity requirement. [Contract, Temperance, } \\
\text { Wisdom, Justice] } \\
\text { 6. We will not be fined and incur significant legal costs for violating these laws. [Contract, Temperance, Wis- } \\
\text { dom, Justice] } \\
\text { 7. We will practice justice, courage, temperance, and wisdom, at least in this matter. [Contract] } \\
\text { 8. We will improve society to the extent that we provide good example and provide good jobs to those who } \\
\text { deserve them. [Contract] }\end{array}$ \\
\hline
\end{tabular}


Let us examine a single example: diversity in the workforce, specifically in hiring. Surprisingly, to those who are not affected by this form of discrimination, many businesses, even at this late date, violate the law and act unethically in this matter. Consider a bare bones critical analysis of hiring a diverse workforce.

Of course, we could elaborate our example further. For example, diversity in the workforce has been shown to contribute to the development of new ideas and improvements in long established practice. We could even simplify the analysis further. We could, for example, consider only matters related to our contractual obligations. This has the benefit of making the analysis short, but it also presents the risk of overlooking important issues. Our implicit contractual obligations are famously difficult to fully identify. But even the brief treatment above demonstrates the practical benefits of acting ethically in our hiring practices. It also illustrates the connection between practical results and Ethical Theories or Virtues, indicated in brackets. We have demonstrated, at least in this case, that ethical conduct in hiring contributes to a manager's influence over business results. The great benefit of such analysis is that a business can afford to do it very thoroughly; once a decision is reached on most problems that decision forms the basis of policy. The analysis need not be repeated.

\section{The Importance Of Feedback}

We could end our discussion here with the idea that we have shown how to make ethical decisions in the business environment. That's true, as far as it goes. Business, however, is not a one time event. Business is a continuing series of events. It is important to note here that we have labeled one of our elements of thought "Anticipated Implications and Consequences." This anticipation of results is very important. It may even encourage us to reflect on the decision we've made and change it. It is at this point that we may find that the implications and consequences of a proposed action include results that we find unacceptable. In that case, we return to our Information, Ideas, and Interpretations to improve them and reach another conclusion. We may then test that conclusion by anticipating its implications and consequences.

But, we also have another problem. When making a decision, we cannot know the actual implications and consequences of acting on that decision. We must wait to observe the actual results. With annoying frequency, we find that actual results differ from our predictions. The road to Hell may very well be paved with good intentions. Now, the question becomes: "What can we do with the results that really occur?" We can learn from them and try to make better predictions in future decision making. This is called feedback. We used purely intellectual feedback above, when we examined anticipated results for acceptability. After we implement our decision, we can do more meaningful feedback analysis on real results. Indeed, a good manager doesn't wait for complete results before using feedback. A good manager follows up on the results of an action and makes corrections whenever something seems to be going wrong. At the very least, feedback should inform our assumptions, our ever developing point of view, the information we use in future decisions, the ideas we employ, and the inferences and interpretations we form in making future decisions. Our goal in the use of feedback is to improve our judgment to make better decisions. The process is continuous. Deming calls it "continuous improvement." Only when we have done our best to improve have we been fully ethical. The virtue of prudence, practical wisdom, requires no less.

\section{Concluding Note On Future Work}

We could repeat this same analysis for other business issues. Indeed, we recommend doing just that. Appendix A provides a form to facilitate such analysis. It is possible to test the ideas presented here by using that form to analyze any important business issue. Tables $5 \mathrm{a}$ and $5 \mathrm{~b}$ serve as a guide and a model. A few obvious blanks have been filled in, but may be altered. The appendix may be copied, or used in its electronic form to facilitate use thereof. Appendix C may help to suggest a few contemporary problems and cases in business ethics.

\section{References}

1. Aristotle. $4^{\text {th }}$ C. BCE (1985). Nicomachean Ethics. Tr. Terence Irwin. Hackett. Indianapolis.

2. Aquinas, Thomas. $13^{\text {th }}$ C. (1966) Treatise on the Virtues, tr. John A Oesterle [Questions XLIX to LXVII from Summa Theologiae] Prentice Hall. Englewood Cliffs, NJ. 
3. Bowie, Norman E. 1998. "Companies Are Discovering the Value of Ethics", USA Today Magazine, January 1998, pp. 22-24.

4. Card, Claudia (ed). 1999. On Feminist Ethics and Politics. University Press of Kansas. Lawrence, KS.

5. Dean, F. Peter. 2001 "The Ethics of Teaching Ethics in Schools of Business". Proceedings of The International Applied Business Research Conference, March 2001, Cancun, Mexico.

6. Deming, W. Edwards. 1986. Out of the Crisis. Massachusetts Institute of Technology. Cambridge, Mass.

7. 1994. The New Economics: For Industry, Government, Education. Massachusetts Institute of Technology. Cambridge, Mass.

8. $\quad$ Gauthier, David. 1986. Morals by Agreement. Oxford University Press.

9. Hobbes, Thomas. 1660. (1962) Leviathan; Or the Matter, Forme, and Power of a Commonwealth, Ecclesiasticall and Civil. Collier Books. New York.

10. Kant, Immanuel. 1785. .(1981) Grounding for the Metaphysics of Morals. Tr. James W. Ellington. Hackett. Indianapolis.

11. _ 1788. (1956) Critique of Practical Reason. Tr. Lewis White Beck. Bobbs-Merrill. Indianapolis.

12. MacIntyre, Alisdair. 1984. After Virtue. University of Notre Dame. Notre Dame, In.

13. Mill, John Stuart. 1863. (1987) Utilitarianism. Prometheus. Buffalo, N.Y.

14. Moore, Nicholas G. 1999. "Ethics: The Way to Do Business", iBusiness and Society Review, v 104, \#3, pp. 305-309.

15. Morris, Tom. 1997. If Aristotle Ran General Motors. Henry Holt \& Co. New York.

16. Paul, Richard and Linda Elder. 2001. Critical Thinking: Tools for Taking Charge of Your Learning and Your Life. Prentice Hall. Englewood Cliffs, N. J.

17. 2001. The Miniature Guide to Critical Thinking: Concepts \& Tools. The Foundation for Critical Thinking. Dillon Beach, Ca.

18. Peiper, Josef. 1966. The Four Cardinal Virtues. University of Notre Dame Press. Notre Dame, IN.

19. Rachels, James. 1993. The Elements of Moral Philosophy, $2^{\text {nd }}$ ed. McGraw-Hill. New York.

20. Rawls, John. 1971. A Theory of Justice. Belknap. Cambridge, Mass.

21. Ross, W. D. 1930. The Right and the Good. The University Press. Oxford.

22. 1 1939. Foundations of Ethics. The University Press. Oxford.

23. Sen, Amartya K. 1987. On Ethics and Economics. Basil Blackwell Ltd. Oxford.

24. Smith, Adam. 1759. (1976) The Theory of Moral Sentiments. D. D. Raphael and A. L. Macfie, eds. Oxford University Press. Oxford.

25. _ 1776. (1976) An Inquiry Into The Nature And Causes Of The Wealth Of Nations. R. H. Campbell and A. SA. Skinner, eds. Oxford University Press. Oxford

26. Valentyne, Peter (ed). 1991. Contractarianism and Rational Choice: Essays on David Gauthier's Morals by Agreement. Cambridge University Press.

27. Wilson, James Q. 1993. The Moral Sense. The Free Press. New York.

28. Wolgast, Elizabeth 1992. Ethics of an Artificial Person: Lost Responsibility in Professions and Organizations. Stanford University Press, Stamford, CA.

29. Unattributed. 2000. "Doing Well By Doing Good". The Economist, April 22, 2000, pp 65-67. 


\section{Appendix A \\ A Template For Analyzing The Logic Of A Business Ethics Issue Or Problem}

Thinking Critically About:

Context:

\begin{tabular}{|c|l|}
\hline $\begin{array}{c}\text { Element of } \\
\text { Thought }\end{array}$ & \\
\hline Purpose & To do the right thing regarding... \\
\hline $\begin{array}{c}\text { Question } \\
\text { Issue } \\
\text { Problem }\end{array}$ & \\
\hline Assumptions & Ethical action in this matter, in the long run, will be rewarded. \\
\hline Point of View & \\
\hline $\begin{array}{c}\text { Information } \\
\text { Data }\end{array}$ & \\
Evidence & \\
\hline $\begin{array}{c}\text { Concepts } \\
\text { Ideas }\end{array}$ & Ethical Theories: Virtue, Contractarianism \\
\hline $\begin{array}{c}\text { Inferences } \\
\text { Interpretations }\end{array}$ & \\
\hline Conclusions & We should/should not... \\
\hline $\begin{array}{c}\text { Anticipated } \\
\text { Implications } \& \\
\text { Consequences }\end{array}$ & \\
\hline
\end{tabular}

\section{Appendix B \\ Ethical Theories for Business Managers}

As we are addressing ethics, there is particular concern about our guiding concepts and ideas. Limiting ourselves to the most widely accepted ethical theories; we have: Moral Sense or Sentiment, Utilitarianism, Kantian Deontology, Rights, Contractarianism, Virtue, and Feminism. (Rachels, 1993) Are all of these ethical theories applicable to business? We might like to believe that one is free to choose any ethical theory, but not all will work in the business environment. This charge may suggest that some ethical theories are inherently false because they fail to be universally applicable. We prefer to think that some ethical theories, possibly all ethical theories, are incomplete. Let us consider the applicability of each of these theories in the business environment.

Before Adam Smith, Chair of Moral Philosophy at the University of Glasgow, wrote his most famous work, An Inquiry Into The Nature And Causes Of The Wealth Of Nations, (1776) he wrote a book that he considered essential to the understanding of his later work. Indeed, Smith assumed that readers of Wealth of Nations were fully familiar with his Theory Of Moral Sentiments (1759) before they undertook reading the later work. Much modern confusion regarding Smith's meaning in Wealth of Nations would be avoided if modern readers fulfilled Smith's prerequisite. It is important here to acknowledge that Adam Smith understood ethical conduct to be fundamental to business behavior. Given Smith's subsequent influence, we should at least look at his idea of ethics. Stoicism was the strongest influence on Smith's ethical and economic philosophy. Along with the Stoics, Smith saw "life according to nature" as the correct human goal; and that nature was harmonious. He therefore tended to take self-command as the whole of the virtues. By self command Smith meant the ability to live in harmony with the natural universe, which was the creation of God and thus beyond human control. The universe was given, our moral obligation was to accept it fully and act in harmony with it. Smith believed that as children of the universe, created by God to inhabit it, humans had a natural sentiment that allowed us to discover that harmony if we allowed the sentiment to operate.

The first problem that arises in implementing this theory is that we don't understand the universe adequately. One could overcome this fact by postulating a moral sentiment that does not require a full understanding of the universe; it might act rather mysteriously. Unfortunately, for Adam Smith, James Q Wilson, and numerous philosophers between, human moral sense or sentiment is so various that we find it entirely unreliable in practice. As at- 
tractive as these and other philosophers make the proposition, there is simply no general agreement among people about the result of each consulting privately one's own moral sentiment. Conflict generally ensues. While the idea is widely, if naively, honored by all those who wish to "Do what seems (or feels) right," this idea is not sufficiently rational or predictable to form a basis for business decisions.

Moral choices based on Utilitarianism (Mill, 1863) must meet three principal requirements: Consequences that maximize happiness (pleasure) as the only morally significant criteria for measuring the goodness of an act; equalitarianism in the treatment of interests of all persons as a prerequisite of the hedonistic calculus; and use of the hedonistic calculus in finding that maximum as the only morally acceptable method of choice.

These are clear criteria that present serious problems in business. Consider criteria 2, equalitarianism, the requirement that the interests of all persons be treated equally. Unfortunately, business managers have a fiduciary obligation to favor the interests of owners above the interests of others. Even though Utilitarianism has no respect for historic promises that constitute duties, the fiduciary duty continues and is enforced both by law and by the fact that owners will dismiss any manager who fails in this duty. There is also the matter of maximization, criteria 1. Managers and owners rarely, if ever, have adequate information to maximize the consequences of any business decision. Nevertheless decisions must be made. One can only try to make an adequate decision, supervise the implementation process, check on results, and make appropriate adjustments. This is not the maximizing process described by Utilitarianism. It is part of the continuous improvement process described by Deming. These considerations suggest that Utilitarianism is unsuitable for the business environment.

Kantian Deontology (Kant, 1785, 1788) requires that we act out of the will to do our duty. It then provides several formulations of the Categorical Imperative that seem clear and understandable. The devil, as usual, is in the details. Business managers have several clearly distinct relationships with different groups of people and therefore distinct duties toward those groups. We can distinguish the interests of owners, employees, customers, suppliers, regulators, etc. These interests, and the manager's corresponding duties to respect them, are not merely different; they often conflict. Some of the duties are mutually exclusive. Kant, however, does not provide guidance that helps us to resolve conflicting duties. This results in an intractable problem for the manager and one that has no apparent process for resolution. Thus, Kantian Deontology proves inadequate to the manager's needs.

W. D. Ross $(1930,1939)$ produced a serious deontological theory in the $1^{\text {st }}$ half of the $20^{\text {th }}$ Century. Ross bases prima facie duties on our intuitions about the relationships that each of us form: husband-wife, child-parent, creditor-debtor, friend-friend, etc. Ross considers these prima facie duties to be conditional, dependant on the situation and relevant moral information. In cases where we are called upon to honor more than one prima facie duty, we are to form a carefully considered opinion to arrive at the duty that is more incumbent than any other. That is our moral obligation in the circumstances. Ross gives us a rough and incomplete guide to the relative importance of various prima facie duties. This list is understood to admit of variation and extension.

\section{Duties stemming from one's own previous actions:}

1. Fidelity -duty to fulfill explicit and implicit promises or agreements into which one has entered.

2. Reparation - duty to compensate wrongful acts previously done to others.

Duties stemming from the previous acts of others:

3. Gratitude - duty to repay others for past favors done for oneself.

Duties stemming from the (possibility of a) mismatch between persons' pleasure or happiness and their merit:

4. Justice - duty to prevent or correct such a mismatch.

Duties stemming from the possibility of improving the conditions of others with respect to virtue, intelligence or pleasure:

5. Beneficence - duty to improve the conditions of others in these respects.

Duties stemming from the possibility of improving one's own condition with respect to virtue or intelligence:

6. Self-Improvement - duty to improve one's condition in these respects.

Special duty to be distinguished from the duty of beneficence:

7. Nonmaleficence - duty not to injure others. 
Although Ross argues elaborately that our moral sense is strong enough to recognize all of our prima facie duties, his moral theory rests ultimately on intuition. Unfortunately, the intuition of different people varies greatly. Some of us even vary in our intuition from time to time. Intuition seems an inadequate grounding on which to base an ethical theory for business managers. Further, Ross, like Kant, provides no principles, beyond intuition, on which to determine among conflicting prima facie duties which is more incumbent upon us.

Contractarianism (Hobbes, 1660; Rawls, 1971; Gauthier, 1986; Valentyne, 2001) is another theory based on duty. It is very clear in its explicit provisions. Implied provisions are another matter; they can be very difficult to understand and act upon. There is no universal understanding of the implied terms of the contract between business and any of the groups with which it forms relationships. We can generally agree to obey applicable law and to honor everyone's right to life. Beyond that, things become murky. We suggest that we employ Rawls' mechanism of the "Veil of Ignorance" to determine the implied terms of the business contract. The veil of ignorance prevents those behind it from knowing anything about their true place in society or their true relationships with others. If we assume that all possible interest groups are represented in a gathering that meets behind a veil of ignorance we might use this fiction to arrive at a set of implied contractual terms acceptable to all. This is, of course, speculation, and there may be better ways to accomplish our end. The point is that we must enforce our best approximation of complete objectivity to arrive at fair contractual terms. Given this preliminary effort and understanding that even implicit contracts may be renegotiated as new information becomes available, we have an understandable and practicable ethical theory for business managers.

There are, nevertheless, some difficulties in Contractarianism. First, as is well known, contracts frequently contain loopholes. There is some question whether, even under a veil of ignorance, we can avoid loopholes that negate the value of our contract. This is the same basic problem that we encounter with Law. There tends to be so much compromise that the result is of minimal value. Second, contract does not accommodate change effectively or efficiently. While terms may be renegotiated, negotiation takes time. The demand for action and the harm that may be done in the intervening time do not often allow enough time for such a complex process. Finally, Contractarianism lends itself best to compliance. The implied contractual provisions for compliance are much simplified as compared to the implied provisions for a general form of Contractarianism. But, compliance implies existing rules or laws. And, we know that rules and laws are the products of compromise that rarely satisfy the all requirements of ethical conduct. So, we may wish to modify our view and suggest that business managers limit their use of Contractarianism to those occasions when compliance is enough to satisfy the requirements of ethics.

Rights are the obverse of duties. That is, each right imposes upon others a duty of respect for that right. The same issues arise for rights as for duties. Both present conflicts with no clear method of resolution. Meaningful ethical compromise is not always possible. Managers need more practicable principles of ethical decision making.

Virtue (Aristotle, NE; Aquinas; Pieper, 1966; MacIntyre, 1984) is inherently one of the most difficult of all ethical theories to practice. Its great advantages are that it is practicable (We've seen that some theories are not) and it does not demand perfection (As do Utilitarianism and Kantian Deontology.) Virtue does become easier with practice; it becomes habit. Study and experience make the virtues understandable.

There appear to be two great difficulties in the practice of Virtue: First, finding the "Golden Mean" between vices of excess and deficiency at which virtue is located in each instance. ,Second, practicing the virtues in concert; that is, not selectively. A virtuous person adopts and practices all the cardinal virtues. Each virtue, practiced at appropriate times, reinforces our ability to practice the others. Frequently, several virtues need be practiced together.

Aristotle helps us with the first difficulty. He says "Do not expect of a thing more exactness than is possible." This is his denial of perfectionism. If we can't locate virtue, the "Golden Mean," precisely, we should come as close as we can; we may improve with practice. The four Cardinal Virtues are: Courage or Fortitude, Justice or Fairness, Temperance or Moderation, and Prudence or Practical Wisdom. Other virtues, such as honesty or equity, are subsumed within these. How do we practice them all together? A serious understanding of virtue makes it clear that one cannot fully practice any virtue in isolation; the virtues are inherently interdependent. This relates to the 
well known fact that it is not easy to "Do the right thing." Consider the following four examples. First, Courage, or Fortitude, the ability to face danger regardless of the fear it inspires, is needed to take every difficult or unpopular action, and ethical actions are rarely easy; Second, Justice, or Fairness, the matter of giving to each what is due, enables us to determine our appropriate action in every relationship; Third, Temperance, or Moderation, involves not only the physical senses, but all of the emotions. It enables us to avoid the vices of excess and deficiency in any area where we are tempted to over react; And, Finally, Practical Wisdom, or Prudence, contributes the ability to find a way to practice the virtues and supports Justice in defining appropriate action.

So, these difficulties are real but manageable. The great difficulty with virtue is finding the dedication and fortitude within oneself to persist in its practice. This is a very personal matter that applies equally to business managers, owners, and all other persons. Business has no special difficulty here; it simply shares the hard task of doing the right thing that we all face. As Virtue poses no extra burden on business managers and owners, and some persons are known to be virtuous, virtue is seen to be practicable in business.

Feminism (Card, 1999) makes at least three important claims: (1) Women have special ethical issues not shared by men; (2) Women suffer disproportionately and differently from some social practices as compared to men; and (3) Women have different ethically relevant insights and abilities compared to men. With regard to the first two claims it appears that the practice of virtue by all makes them disappear. Like any oppressed group, and women have historically been an oppressed group, women have every right to claim that we should change our ways. They even have a right to demand that we make amends. Let's do it! That would simply require the practice of virtue with an emphasis on justice. With regard to the third claim we face the problem that feminism can best be practiced by women. There is even an implication in some feminist works that ethics is an exclusively female domain. Since many managers and owners are men, such a theory is not generally applicable in business. We suggest a more universally applicable theory, namely virtue, that addresses the issues of feminism and is practicable by all.

\title{
11. Final Thoughts
}

That leaves us with two mainstream ethical theories from which to choose: Virtue and, under some circumstances, Contractarianism. Until more information is available we may feel free to practice either or both in the context of business.

\section{Appendix C Some Contemporary Problems in Business Ethics}

\author{
Issues: \\ Conflicts of Interest \\ Consumer Protection \\ Discrimination based on: Gender, Lifestyle, Age, Race, Culture, National Origin \\ Diversity \\ Downsizing \& Layoffs \\ Employee Duties \\ Employee Rights \\ Employer Duties \\ Employer Rights \\ Environmental Disregard \\ Environmental Pollution \\ Equal Employment Opportunity \\ Fair Use and Distribution of Information \\ Harassment based on: Gender, Lifestyle, Age, Race, Culture, National Origin \\ Insider Trading \\ Leadership and its example \\ Management Responsibilities
}


Marketing Practices including: Deception, Product Quality, Product Misrepresentation, Distribution Policies, Fairness in Pricing,

Market Timing

Mergers

Multinational Corporate Issues including: Relativism, Bribery, Collusion, Price Fixing

Privacy of Employees, Customers

Product Safety

Social Responsibility

Spying

Whistle Blowing

White Collar Crime

Working Conditions

\section{Cases:}

Adelphia

AOL Time Warner

Arthur Andersen

Bristol-Myers Squibb

Columbia/HCA

Computer Associates

Citigroup

Credit Suisse First Boston

Deloitte, Touche, Tomatsu

Dynergy

Edison Schools

E. F. Hutton

Enron

Ernst and Young

Exxon

Firestone

First Boston

Ford Motor Co.

Global Crossing

Halliburton

HealthSouth

iCapital Markets

Imclone

J. P. Morgan Chase

Kmart

KPMG

Lucent Technologies

Merrill Lynch

Monsanto

Network Associates

PNC Financial Services

PriceWaterhouse

Quest Communications

Reliant Resources

Rite Aid

Sears

Trump Hotels

Tycho

Waste Management 
Worldcom

Xerox

A Few Resources for Case Research

Internet News Services including the major TV networks, PBS, NPR, and PRI

www.http.thememoryhole.org

The New York Times

The Wall Street Journal

Forbes Magazine

Fortune Magazine

Fast Company Magazine

Business Ethics Magazine

Annual Editions: Business Ethics (Latest edition)

Business Ethics Quarterly

The Journal of Business Ethics

Notes 
Notes 